\title{
DE VERANTWOORDELIJKHEID VAN DE ACCOUNTANT VOOR HET BEKEND MAKEN VAN GEBEURTENISSEN DIE NA DE BALANSDATUM DOCH VOOR DE PUBLICATIE VAN HET JAARVERSLAG PLAATS VINDEN
}

\author{
door D. P. Portey
}

Het bovengenoemde probleem wordt besproken door de oud-voorzitter van het A.I.A., de heer Edward B. Wilcox, in het nummer van April 1950 van ,The Journal of Accountancy".

In het hierna volgende wordt eerst het Amerikaanse standpunt weergegeven terwijl aan het slot getracht zal worden te komen tot het formuleren van een eigen standpunt.

De Heer Wilcox is van oordeel dat op het terrein van het uitbrengen van accountantsrapporten, bekwaamheid, ervaring, integriteit en een gezond oordeel een grotere rol spelen dan voorschriften. Er bestaan echter te dien aanzien algemeen aanvaarde ,accounting principles and auditing standards", zekere normen dus die van grote betekenis zijn. Deze normen sluiten het eigen oordeel bij de toepassing daarvan weliswaar niet uit, maar ze verkleinen toch het terrein waarop dat eigen oordeel zich geheel vrij kan uiten. Degene die verantwoordelijk zijn voor de inhoud van jaarverslagen, dienen zich primair te laten leiden door goede trouw. Omtrent al datgene wat als aanvulling op het jaarverslag, gezien als financieel verantwoordingsstuk van een afgelopen periode, openbaar gemaakt behoort te worden, bestaat misschien wel de meeste onzekerheid t.a.v. gebeurtenissen die na de balansdatum plaats vinden.

Wanneer we hierover spreken, dan dient eerst vastgesteld te worden, welke soort gebeurtenissen we op het oog hebben. Het staat n.l. vast, dat een deel van onze contrôle werk steeds na de balansdatum plaats vindt en daardoor dus automatisch ook gebeurtenissen in de contrôle betrekt, die na die datum plaats vinden. We denken hierbij b.v. aan de contrôle van de uitstaande debiteuren-saldi en de beoordeling van de waarde daarvan en aan de contrōle en de waardering van de goederenvoorraad. De inlichtingen die dan verkregen worden, worden bij het vellen van ons oordeel gebruikt en het hangt dus af van het tijdstip waarop na de balansdatum de contrôle wordt verricht, in welke mate van deze feiten gebruik gemaakt zal kunnen worden. Als hier dus getracht wordt een lijn te trekken, zal men tot de ontdekking komen dat deze lijn nogal vaag moet zijn. We kunnen n.l. erkennen dat we in bepaalde gevallen de verplichting hebben om te openbaren wat te weten, maar dat we niet de plicht hebben om het te weten.

$\mathrm{Er}$ is ook geen duidelijke grens aan te geven tussen die feiten die van invloed zijn op de balans als zodanig en andere die niet direct van invloed zijn op de balans, maar toch de financiële positie als geheel raken. Een grensgeval zou men kunnen zien in het geval b.v. de activa van een onderneming na de balansdatum als zakelijk onderpand voor een lening worden verbonden. De schuld is dan als nieuw feit aan te merken, maar ook de status van de activa verandert, door de verpanding. De status van deze activa zou echter in nog ernstiger mate aangetast kunnen worden door een proces dat de onderneming na de balansdatum wordt aangedaan, zonder dat de activa als zodanig hier direct bij betrokken worden.

Andere voorbeelden van veranderingen na de balansdatum doch voor

$\mathrm{m}$ a b blz. 251 
publicatie kunnen b.v. zijn, de aankoop van belangrijke productie-middelen, veranderingen in de kapitaalstructuur en dergelijke.

Wanneer we willen stellen, dat dit soort gebeurtenissen openbaar gemaakt dienen te worden, dan zullen we stuiten op de moeilijkheid, dat sommige hiervan niet door onderzoek van de boekhouding kunnen blijken. Toch kunnen deze van grote invloed op de toekomstige gang van zaken zijn. Schrijver noemt als voorbeelden, verandering in de leiding van de onderneming, nieuwe uitvindingen, stakingen e.d. We kunnen t.d.a. het standpunt innemen, dat het openbaar maken van deze feiten tot de taak van de leiding van de onderneming behoort en niet tot de taak van de public accountant. De accountant is n.l. verantwoordelijk voor zijn oordeel omtrent de financiële publicaties in het jaarverslag en de wijze waarop dit oordeel wordt kenbaar gemaakt. Wat daarbuiten gaat valt buiten zijn verantwoordelijkheid. De moeilijkheid schuilt echter in de toepassing van dit standpunt in speciale gevallen. Sommige gebeurtenissen hebben nu eenmaal een gemengd karakter en er zijn talrijke grensgevallen, waarvan niet zo zonder meer gezegd kan worden dat ze niet tot het terrein van de accountant behoren. Schrijver geeft drie redenen waarom de accountant aan deze gebeurtenissen van gemengd karakter niet zonder meer voorbij kan gaan n.l.:

1. De gebeurtenissen die na de balansdatum plaats vinden, hebben bijzondere betekenis, omdat ze nog geen invloed hebben kunnen uitoefenen op de resultaten en op de financiële positie. Dit zou wel het geval geweest zijn als ze voordien hadden plaats gevonden. Hierdoor kan de jaarrekening die dateert van voor de gebeurtenis in betekenende mate misleidend zijn ten opzichte van de toestand zoals die na de gebeurtenis is geworden.

2. De stappen die leiden van de gebieden waaromtrent deze verantwoordelijkheid duidelijk is, naar die waarop dat niet het geval is, kunnen zo klein zijn dat het probleem waar de scheidingslijn getrokken dient te worden, moet worden opgelost.

3. De Securities Act 1933 en de Securities and Exchange Act 1934 scheppen de mogelijkheid van zekere verplichtingen ten aanzien van het probleem dat ons bezig houdt.

Krachtens deze wetten is het n.l. verboden: ,to omit to state a material fact which would permit statements to be misleading in the light of the circumstances under which the were made".

Schrijver ziet geen wezenlijk verschil in verantwoordelijkheid in het geval de accountant een prospectus of een jaarrekening certificeert. De moeilijkheid schuilt in het vaststellen wat als ,, a material fact" met betrekking tot gebeurtenissen na de balansdatum moet worden aangemerkt. In het artikel worden enkele voorbeelden gegeven ontleend aan rechtspraak van de Securities and Exchange Commission (S.E.C.). Ik vermeld de volgende gevallen:

1. Een publicatie van September 1939 betreffende de „Potrero Sugar Company", een in Mexico werkende onderneming.

In de ,registration Statement" werd een rooskleurig beeld gegeven van de vooruitzichten. Nagelaten werd echter te wijzen op ongunstige weersomstandigheden en de ongunstige arbeids- en politieke situatie in Mexico. Dit waren dus feiten en omstandigheden die niet op accountantsterrein liggen. Het bestuur van de onderneming werd verantwoordelijk 
geacht, omdat in het prospectus ,,an untrue statement of a material fact" voorkwam.

$\mathrm{De}$ in het prospectus opgenomen verlies en winstrekeningen werden niet misleidend geacht bij gebreke van het feit dat de invloed van zekere arbeidssituaties niet tot uitdrukking was gebracht. Als doel van de verlies en winstrekening werd n.l. genoemd het bedrijfsresultaat weer te geven over de periode waarop ze betrekking heeft. Hieruit zou men kunnen opmaken dat de invloed van gebeurtenissen daarna, geheel buiten beschouwing zou kunnen blijven. Dit is echter in strijd met een noot die de S.E.C. bij haar uitspraak plaatste en die als volgt luidt: „It may be noted that the registrant's balance sheet was certified on May 4, 1936. If the crop had actually proved to be a failure subsequent to the date of the balance sheet but before the date of certification, it would have been the duty of the certifying accountant to call attention to that fact."

Een geheel ander geluid dus. De schrijver van het artikel verklaart dit uit het feit dat de publicatie plaats vond in September 1939. Wat hiermede precies bedoeld wordt, is mij niet duidelijk, doch het is mogelijk dat verband gezien wordt met het uitbreken van de tweede wereldoorlog, waardoor de noot misschien niet voldoende doordacht is in het verband van de uitspraak zelf.

2. Een publicatie betreffende de "Central Specialty Company", van Februari 1942.

Hier werd het prospectus geacht ,untrue or misleading statements" te bevatten, omdat er optimistische halve waarheden in voorkwamen. Er was n.l. medegedeeld dat de arbeidsverhoudingen zeer bevredigend waren, terwijl in werkelijkheid een staking dreigde. De verlies en winstrekening werd niet onjuist geacht, uit hoofde van het feit, dat niet de aandacht was gevestigd op de na de afsluitdatum ontstane hogere arbeidskosten, als resultaat van de hogere lonen en op de mogelijke verdere stijging der lonen. De S.E.C. stelde vast, dat er geen bewijs geleverd was dat de verlies en winstrekening de resultaten over de periode waarop ze betrekking had, niet juist weergaf.

3. Een publicatie betreffende de „Colorado Milling and Elevator Company", van December 1943.

Dit is een duidelijk geval waarin de publicatie van de financiële gegevens ontoereikend geacht werd. Tussen de datum van het afsluiten van het jaarverslag n.l. 31 Mei 1943 en de datum van het indienen der registratie aanvraag krachtens de Securities and Exchange Act, op 6 Augustus 1943, hadden belangrijke financiële veranderingen plaats gevonden. Ongeveer $90 \%$ van het aandelen-kapitaal was n.l. op 22 Mei 1943 in andere handen overgegaan. Na 31 Mei ' 43 was de belangrijke effectenportefeuille van de maatschappij verkocht en een dividend van 7 millioen dollar in contanten uitgekeerd. Het grootste deel hiervan was natuurlijk terecht gekomen in de zakken van de nieuwe aandeelhouders.

Gevolg hiervan was vermindering van de winstmogelijkheden. De in het prospectus opgenomen verlies en winstrekeningen over een periode van 9 jaar, die ten doel hadden de toekomstige aandeelhouders inzicht te geven in de winstmogelijkheden van de onderneming, konden deze functie dus niet meer vervullen. Het achterwege laten van enige mededeling omtrent de plaats gevonden veranderingen werd dan ook misleidend geacht.

Uit het voorgaande moge volgens schrijver blijken, dat de public 
accountant zich niet geheel kan onttrekken aan de verantwoordelijkheid voor het openbaar maken van datgene wat na de balansdatum is gebeurd. Met de erkenning hiervan begeven we ons echter in betrekkelijk onbekend vaarwater en het komt schrijver nuttig voor, dit water wat nauwkeuriger af te bakenen.

Wanneer wij spreken over een "material fact", bestaande tengevolge van een gebeurtenis die na de balansdatum heeft plaats gevonden, dan bedoelen we daarmede een zodanig feit, dat hierdoor de financiële positie of de winstcapaciteit in belangrijke mate afwijkt van het beeld dat hiervan in de jaarrekening is gegeven. Voor gebeurtenissen die liggen op accountantsterrein bestaat ten aanzien van het begrip ",material fact" geen grote moeilijkheid. Dit begrip is bekend uit de „,rules of professional conduct" en reeds jaren lang zijn de accountants gewoon dit begrip te hanteren.

Het is de plicht van de accountant er zorg voor te dragen dat hetzij in zijn rapport, hetzij in het jaarverslag of elders van een dergelijk feit melding wordt gemaakt. Deze plicht van de accountant is duidelijker ten aanzien van gebeurtenissen die liggen op accountantsterrein, dan ten aanzien van die bij welke dat niet het geval is. Zoals echter in het voorgaande reeds is opgemerkt, zijn er gebeurtenissen die een gemengd karakter dragen, terwijl andere die niet op accountantsterrein liggen een verrijkende invloed kunnen hebben op het beeld van de jaarrekening. In bepaalde extreme gevallen kan de verantwoordelijkheid voor het bekend maken van deze feiten mede tot de taak van de accountant gaan behoren, niet zo zeer door de aard der gebeurtenissen, als wel door het effect op de gepubliceerde cijfers. Daarentegen moet goed begrepen worden, dat de certificerende public accountant niet de plicht heeft van, of de verantwoordelijkheid draagt voor, het openbaar maken van gebeurtenissen waarover hij in geen enkel opzicht een juist oordeel kan uitspreken. Bijvoorbeeld de dood van een leidende figuur, kan evengoed een verlies als een zegen voor een onderneming zijn. Evenmin is het gewenst commentaar te leveren op algemeen bekende economische of andere verschijnselen, of gebeurtenissen (b.v. het uitbreken van een oorlog waarbij ook het eigen land betrokken is). Het criterium zal hier dus moeten liggen in het algemeen bekend $z$ ijn.

Wanneer we het eens zijn over de aard der gebeurtenissen die openbaar gemaakt dienen te worden, dan rijst nog de vraag hoe we achter deze gebeurtenissen komen. Schrijver meent dat de volgende middelen kunnen dienen:

1. Een "reasonable investigation", uitgevoerd met inachtneming van algemeen aanvaarde contrôle normen.

2. Een aanvullend onderzoek, beperkt tot een doublure van de contrôle van zekere critisch gekozen onderdelen, aangevuld of gewijzigd al naar de omstandigheden. De basis van dit aanvullend onderzoek zal in vele gevallen kunnen zijn het inwinnen van informaties bij de leiding. hetzij schriftelijk of mondeling. Deze inlichtingen kunnen de aanknopingspunten vormen voor eventuele verdere onderzoekingen.

Tot zover de schrijver van het artikel. Teneinde het Amerikaanse standpunt in deze niet van één zijde te belichten, citeer ik wat Montgomery in de 7e druk van "Auditing" hieromtrent zegt. (Zie Hoofdstuk 7. .Financial Statements" blz. 103 en 104.)

,Disclosure in Financial Statements of Events Subsequent to the Balance Sheet Date. - The auditor is necessarily present at the client's

$\mathrm{m}$ a b blz. 254 
office for a certain period of time after the date of the balance sheet under examination, because his field work requires some time for its completion. The auditor always has considered certain postbalance sheet transactions for the light they shed upon the accounts at the balance sheet date. For example, the best proof of the worth of an account receivable at the balance sheet date is its subsequent collection; if a liability, uncertain at the balance sheet date, is setlled by negotiation before completion of the auditor's examination, the basis of the settlement should be reflected in the balance sheet.

There may come to the auditor's attention transactions which would not properly be reflected in the financial statements under examination, because they relate entirely to the subsequent period, but which nevertheless are of interest to a prospective investor or creditor in his consideration of the financial statements. Such events might be changes in capital structure, expansion of plant facilities, or development of new products or new markets. There is a growing tendency to disclose major transactions of this sort in a footnote. There are other borderline events, but in general if they are of a character which would not have required disclosure had they occurred prior to the year end, it is not usual to mention them in the financial statements.

The responsibility for ascertaining and disclosing material transactions or events subsequent to the date of the balance sheet rests with the management, although the auditor may learn of them through inquiry. inspection of minutes, or substantiation of the accounts for the year under review. The auditor must form an opinion as to the necessity for and the adequacy of disclosure of those subsequent events that have come to his knowledge."

Evenals onze Amerikaanse collega's hebben wij ons t.a.v. onze gedragingen als accountant te houden aan zekere normen. Een deel van deze normen vinden we gecodificeerd in ons Reglement van Arbeid. Tevergeefs zullen wij echter in dit R. v. A. zoeken naar voorschriften die ons precies aangeven, hoe we ons t.a.v. het probleem dat ons bezig houdt hebben te gedragen. Wel vinden we in de artikelen 14 en 16 belangrijke aanwijzingen; er blijft echter voldoende ruimte voor subjectieve interpretatie.

Wettelijke bepalingen zoals die in Amerika in de Securities Act 1933 en in de Securities and Exchange Act 1934 voorkomen kennen wij in ons land niet. Wel heeft ons hoogste rechtscollege zich in een fiscaal geschil eens bezig gehouden met de vraag, welke invloed gebeurtenissen na de balansdatum op de waardebepaling per de balansdatum kunnen hebben, doch dit geding raakt slechts zeer zijdelings ons probleem. Toch acht ik de uitspraak van de H.R. (B. 7687 d.d. 18 Juni 1943) op deze plaats wel vermeldenswaard. Beknopt samengevat waren de overwegingen van de H.R.:

,.dat goed koopmansgebruik medebrengt, dat de bepaling van de waarde van goederen en voorraden op het einde van een kalender-boekjaar geschiedt naar de feiten en omstandigheden, zoals die op dat tijdstip lagen, doch dat voor de vraag, welke die feiten en omstandigheden zijn geweest, de koopman zich richt naar de gegevens hieromtrent, welke hem ten tijde van het opmaken van de balans ten dienste staan, ook al zijn ze hem eerst na her einde van het kalender-boekjaar bekend geworden".

Ik ga aan deze uitspraak verder zonder commentaar voorbij. 
Ten aanzien van het onderwerp dat ons in hoofdzaak bezig houdt, zou $i k$ de feiten die zich kunnen voordoen tussen het einde van de verslagperiode en de publicatie van het jaarverslag, in 2 hoofdgroepen willen indelen, t.w.:

A. Feiten die liggen op accountants en of administratief terrein.

$B$. Feiten die niet op het onder A. genoemde terrein liggen.

Over feiten van betrekkelijk gering belang, b.v. enkele activa zijn na de balansdatum als zakelijk onderpand verbonden voor een opgenomen lening, investeringen in nieuwe productiemiddelen e.d. wil ik hier niet spreken. Naar mijn mening behoeft de accountant geen bezwaar te maken als hieromtrent in de jaarstukken geen mededelingen voorkomen. Generaliseren is echter ook in deze uit den boze en ik kan me indenken, dat ook deze feiten in bepaalde gevallen van voldoende belang worden geacht om mededelingen hieromtrent gewenst te achten.

Tot goed begrip wil ik nog even vooropstellen dat ik bij de bespreking van het onderhavige probleem denk aan de publicaties van naamloze vennootschappen, waarvan de aandelen mede in handen zijn van aandeelhouders die niet direct of indirect bij de leiding van de onderneming zijn betrokken.

Als voorbeelden van de onder $A$. vallende feiten noem ik:

1. Verlies van een belangrijk proces.

2. Verlies van belangrijke vermogensbestanddelen door rampen, (oorlogsgeweld, brand, explosie e.d.).

3. Belangrijke prijsdaling van voorraden.

4. Verwacht verlies op lopende orders door gebeurtenissen na de balansdatum.

Het spreekt bijna vanzelf dat deze voorbeelden nog met andere uitgebreid zouden kunnen worden, maar ik meen dat we aan deze 4 voorbeelden als "werkvoorbeelden" voldoende hebben. In al deze gevallen behoort hiervan n.m.m. in het jaarverslag melding gemaakt te worden en wel op zodanige wijze, dat de invloed van deze feiten in cijfers tot uitdrukking gebracht wordt. In de meeste gevallen zullen dit slechts globale cijfers behoeven te zijn. Ik acht het de plicht van de accountant, als vertrouwensman van het maatschappelijk verkeer, er voor te waken dat de mededelingen die de belanghebbenden via het jaarverslag bereiken, niet alleen een juist beeld geven van de gang van zaken in de verslagperiode en van de toestand van de onderneming aan het eind van die periode, maar ook dat deze mededelingen niet door gebeurtenissen na die datum een belangrijk deel van hun waarde hebben verloren. De vraag rijst dan, op welke wijze deze mededelingen aan belanghebbenden gedaan dienen te worden. Primair acht ik dit de taak van de directie. Tot de taak van de accountant behoort het echter n.m.m. er op toe te zien, dat de verantwoording en voorlichting van de directie via haar publicatie van het jaarverslag, niet door gebeurtenissen die liggen na de balansdatum tot halve waarheden geworden zijn.

In al die gevallen waarin de financiële positie en of de winstcapaciteit door gebeurtenissen liggende tussen de balansdatum en de datum van publicatie van het jaarverslag, belangrijk afwijkt van het beeld dat hiervan in het jaarverslag wordt gegeven, behoort de accountant dus van zijn 
afwijkend standpunt te doen blijken. Op welke wijze dit dient te geschieden kan hier onbesproken blijven.

Tot slot nog enkele voorbeelden van feiten die ik tot de categorie B. gerekend zou willen zien:

1. Verandering in de leiding der onderneming.

2. Nieuwe uitvindingen of toepassing van nieuwe werkwijzen of procédé's.

3. Werkstakingen.

De hier genoemde feiten behoeven voor de accountant m.i. geen aanleiding te zijn op publicatie hiervan te staan. De gevolgen hiervan zullen i.h.a. niet of zeer moeilijk door de accountant beoordeeld kunnen worden, terwijl het in cijfers uitdrukken van de gevolgen uitgesloten geacht moet worden. 